gaseous products finding their normal markets; the coke is then subjected to the water-gas process so as to produce a mixture of carbon monoxide and hydrogen. By the use of various catalysts, together with, if necessary, additional hydrogen, liquids of various types are obtainable. Such catalytic conversion has been investigated in Germany by Fischer and the Badische Anilin und Soda Fabrik, in France by Patart and his co-workers, and in England by Prof. G. T. Morgan at the Chemical Research Laboratory, by Prof. W. A. Bone at the Imperial College of Science and Technology, and by Imperial Chemical Industries, Ltd. Dr. Franz Fischer, of Mulheim, working at atmospheric pressures, has produced liquid and solid hydrocarbons of the petroleum series. Oxygen-containing products are absent, and a yield of $100 \mathrm{gm}$. of solid, liquid, and liquefiable hydrocarbons is claimed from each cubic metre of water-gas.

\section{CoNCLUSION}

On the technical side much has been achieved. By the carbonisation of coal, liquid products suitable for use in internal combustion engines or in furnaces can be obtained directly, but not in large quantities compared with the amount of coal used; in such processes the greatest stress must be laid upon the markets for the solid and gaseous products, oil and petrol being merely by-products. By the hydrogenation of petroleum, or of low temperature tar and certain fractions of high temperature tar, large percentage yields of motor spirits can be obtained.

By the direct hydrogenation of a suitable coal some 160 gal. of motor spirit per ton of coal treated can be made, and even when the additional coal for the process is taken into account the yield is $80 \mathrm{gal}$. and the thermal efficiency is 43 per cent. Alternatively, motor spirit can be obtained synthetically either in the form of alcohols or of hydrocarbons, by first converting the coal into carbon monoxide and hydrogen, but not, under present conditions, so cheaply as by hydrogenation.

In view of the mechanical difficulties of working, on a large scale, a process involving simultaneously high pressures and high temperatures, the technical progress of coal hydrogenation has been surprisingly rapid. It is now undoubtedly possible to manufacture petrol from coal. The commercial prospects of the process are, nevertheless, uncertain, for it is always difficult to forecast the future of a synthetic, in competition with a natural, product.

\title{
The Royal Academy
}

$\mathrm{E}^{\mathrm{N}}$ NTERING the galleries of Burlington House with a mandate to seek for "points of particular scientific interest", I went first to the Sculpture Rooms, where my attention was arrested by the bust of Sir Patrick Geddes (1427), whose recent death has left a gap in the ranks of science which will not easily be filled. The character which emerges in Mr. Pibworth's rendering is that of the acute analytical mind; the contemplative philosopher does not appear. It is interesting to consider in this connexion the appreciations which have appeared in the Press from a number of Geddes's friends, each reflecting a different facet of his many-sided mind. His influence in the world was undoubtedly due in large measure to the great variety of persons with whom he was able to make sympathetic contact.

The full-size model of the Native War Memorial, Lagos (1382), by Mr. James A. Stevenson, admirably illustrates the statuesque character which is so marked in many of the African peoples. I suggest that such successful generalisation of the attributes of existing races is of "more particular scientific interest" than the emphasis of simian characters, now so popular, which inevitably suggests the 'missing link' as the true ideal of the human form.

Among the oil paintings, well placed at the end of Gallery II., "Spoleto, Italy" (103), by Mr. Osmund Pittman, is a fine composition, showing the hill town above a river spanned by an arched bridge (the water reflecting the colour of the sky), the architectural forms pleasing in the simplicity common to Mediterranean building, with plain plastered wall, small windows, low roofs, and ab- sence of chimneys. In " Old Mill House, Avila, Spain " (150), by Mr. Oliver Hall, R.A., severity of architecture and a stern landscape are in fine accord, and the scheme of tone and colour is skilfully continued in the design of frame which this painter habitually employs.

"Last Rays : Northern Ireland" (194), by Mr. Julius Olsson, R.A., is one of those studies of sunset colour upon the sea which cannot be too often repeated, for the effect is as fleeting as it is beautiful. Mr. S. J. Lamorna Birch has a study of the columnar granite cliffs of the Land's End (225) rising from smooth, flat sands, across which the long, low waves come gliding in. "Harbour" (262), by Mr. George Graham, recalls for our pleasure the perfection with which the forms of hull and sail, of spars and rigging, are outlined by the plain background of water and sky in the estuaries of a low-lying shore.

Mr. Joseph Farquharson, R.A., has a most poetic study of the stately columns of a fir forest among the mountains (339), with solemnity of deep, rich colour.

Mr. Guy Kortright's " Springtime in Dalmatia" (557) and "August Heat: Corsica" (623) are remarkable studies in the essential forms of the land, although not, I think, equally successful in conveying the transitory qualities of the seasons. "Twilight in the Downs" (604), by Mr. William Clarkson, renders in a harmony of tones the mystery of the dying day.

Among the water-colours, Mr. Frank Baker's "Widecombe-in-the-Moor" (781) gives us the everwelcome scene of church and hamlet backed by swelling hills, seen in the soft sunshine of the 
English summer. In Gallery No. VI., Mr. Samuel Smith's dry point of "Richmond Castle, Yorkshire" (1165), is a fine study of architecture set between the water and the sky.

The Architectural Room provides much food for thought. Looking at the dignified and harmonious designs of residential and business blocks in framework of steel, we wonder why the appearance of our great cities is not more pleasing, and are impelled towards the hopeful conclusion that the source of our present discontent is the mixture of the cubical with the older, gabled forms; and that all may once more be well when the new pattern has complete possession. VAUGHaN CoRNISH.

\section{News and Views}

\section{Georges Cuvier}

ON May 13 occurs the centenary of the death of the distinguished French naturalist and statesman, Baron Cuvier, often referred to as the founder of comparative anatomy. "It was", says von Zittel, "the creative genius of Cuvier that erected Comparative Anatomy into an independent science, and defined principles upon which the investigation of fossil Vertebrates could be carried out with accuracy. ... His greatness rests upon the magnificent work that he accomplished in the domain of Vertebrates, upon the scientific method which he founded for the identification of fossil bones, and upon his successful demonstration that the primeval mammals were not mere varieties of living forms, but belonged to extinct species and genera." Moreover, Cuvier, by his skill as a lecturer and writer and by his commanding personality, attracted many to the study of geology and palæontology, while, as one of the inspectors appointed by Napoleon to reorganise the schools and colleges of France and other countries, he did much to introduce and extend the teaching of natural history and other sciences.

Cuvier, who was made a baron in 1819 , was born on Aug. 23, 1769, at Montbéliard, then belonging to the Duchy of Württemberg, his full name being Georges Léopold Chrétien Frédéric Dagobert Cuvier. A child of unusual gifts, he received his earliest education from his mother, but at the age of fifteen years became a student at the Academy of Stuttgart, and at nineteen was a tutor in a nobleman's family in Normandy. Here he passed the years of the Revolution, little affected by the events of the time, but meanwhile extending his knowledge of natural history. The turning point in his career came with his friendship with the Abbé Tessier, through whom he went to Paris, where he quickly attained to a distinguished position. In 1795 he was given a post in the Museum, in 1796 was made a member of the Institut de France, in 1800 he succeeded Daubenton at the Collège de France, and in 1803 he was made permanent secretary to the Academy of Sciences. His works included his "Leçons d'anatomie comparée" (1801-5), "L'Anatomie des mollusques" (1816), "Le Règne animal " (1817), "Les Ossements fossiles de quadrupèdes" (1821-24), and his uncompleted "Histoire naturelle des poissons". His éloges, published in three volumes, included those on Priestley, Banks, Delambre, Berthold, Lacépède, and Davy. For some years he was Chancellor of the University of Paris, and both under Napoleon and his successors he held high State appointments. His death was regarded as a national calamity, and his burial in the Père la Chaise cemetery was attended by a large concourse of people.

\section{Portraits at the Royal Academy}

IN addition to the paintings and other studies at the Royal Academy mentioned by Dr. Vaughan Cornish in his article published elsewhere in this issue, the exhibits include portraits of the following : Dr. Alfred Cox, medical secretary to the British Medical Association, 1912-32 (190), by Sir Arthur Cope; Dr. Thomas Sinclair, M.P. for the Queen's University of Belfast (210), by Mr. George Harcourt; Prof. Blair Bell, of the University of Liverpool (261), by Mr. John A. A. Berrie; Prof. R. S. Troup, director of the Imperial Forestry Institute, Oxford (332), by $\mathrm{Mr}$. Peter A. Hay; Sir Robert Witt, vice-chairman of the Institute of Industrial Psychology (377), by Mr. Oswald Birley; Dr. W. W. Vaughan, headmaster of Rugby School, 1921-31 (398), by Mr. Glyn Philpot; Mr. F. Howard Livens, vice-president of the Institution of Mechanical Engineers (447), by Mr. Arthur G. Walker; Dr. Bevan Lean, headmaster of Sidcot, Somerset, 1902-30 (542), by Mr. Bertram Priestman; Lieut.-Gen. the Right Hon. J. C. Smuts, president in 1931 of the British Association (594), by Mr. John Wheatley. Among the statuary we notice: Sir Ernest Shackleton (1390), statue, and Lord Melchett (1392), relief, both by Mr. Sargeant Jagger ; Sir Ambrose Fleming, emeritus professor of electrical engineering in the University of London (1492), bronze bust, by Mr. George H. Paulin; Sir Jagadis Chandra Bose, director of the Bose Research Institute, Calcutta (1564), bronze head, by Marguerite Milward.

\section{Science in Drama}

THE need for men of science to appreciate the sociological consequences of their work, alongside the equally vital necessity for politicians to realise what science opens up in the field of social and industrial reconstruction, have often been stressed in these columns. It is, therefore, with much interest that we note the production at the Globe Theatre, London, of "Wings over Europe", by Robert Nichols and Maurice Brown. The authors avail themselves of a legitimate poetic licence. A young and brilliant scientific worker with a rather simple sociological outlook discovers how to release the energy of the atom, and offers to present his discovery to the British cabinet, provided the cabinet will at once take such steps as should now be possible to eliminate poverty and reduce all work to the barest minimum. The confusion and despair of a cabinet of men ignorant

No. 3262, Vol. 129] 